\title{
Implementasi Kebijakan Program Keluarga Berencana Dalam Rangka Peningkatan Kesertaan KB Pria di Kecamatan Kepanjenkidul Kota Blitar
}

\author{
Kusuma Wibawa, Imam Baehaki \\ Magister Manajemen Universitas Islam Kadiri
}

\begin{abstract}
Abstrak
Tujuan Penelitian adalah mendiskripsikan implementasi kebijakan peningkatan KB pria dalam program Keluarga Berencana di Kecamatan Kepanjenkidul Kota Blitar 2.Mengetahui dan menganalisis faktor-faktor yang mempengaruhi implementasi kebijakan peningkatan kesertaan KB pria.

Penelitian ini menggunakan pendekatan fenomenologis. Hal inimengingat tujuan utama dari penelitian ini adalah untuk memahami secara mendalam terhadap fenomena yang dijadikan sasaran penelitian, yakni masih cukup rendahnya cakupan kesertaan KB pria. Dalam memaknai pemahaman ini, peneliti akan mencoba menarik berbagai generalisasi atau teori yang dapat digunakan untuk perkembangan ilmu itu sendiri atau untuk dijadikan dasar bagi kepentingan aplikasi teori dalam kehidupan masyarakat.

Hasil Penelitian menunjukkan bahwa : Pertama, partisipasi laki-laki (suami) dalam ber-KB relatif masih rendah. Hal ini terlihat dari temuan studi ini, yaitu dari seluruh responden (laki-laki) sebanyak 8,35 persen yang menggunakan kontrasepsi vasektomi, selebihnya perempuan (istri) yang menggunakan metode kontrasepsi. Kedua, beberapa kendala yang menghambat partisipasi laki-laki dalam ber-KB adalah adanya kekhawatiran mengganggu kejantanan, impotensi, malu karena menjadi pergunjingan di masyarakat. Ketiga, strategi yang perlu dikembangkan untuk meningkatkan partisipasi laki-laki dalam ber-KB antara lain adalah: 1) untuk mengurangi berbagai kekhawatiran suami maupun istri tentang risiko ber-KB Pria, khususnya vasektomi, perlu dilakukan sosialisasi yang lebih intensif, dan kampanye Masyarakat, melalui media massa, yang menampilkan bintang iklan yang populer, sehingga keikutsertaan dalam Program KB Pria tidak lagi dianggap sebagai sesuatu yang tabu atau memalukan. Sosialisasi ini perlu dilakukan tidak hanya bagi kaum pria, tetapi juga bagi kaum perempuan, karena dalam kenyataan tidak jarang terjadi justru kaum perempuan sendiri yang menjadi penghalang kemungkinan suami mereka ikut serta dalam Program KB; 2) Untuk mempermudah akses para suami yang ingin melakukan vasektomi, ada baiknya jika dikembangkan berbagai pelatihan bagi para dokter atau tenaga medis lainnya dalam melakukan praktik vasektomi agar bisa dieliminasi sekecil-kecilnya kemungkinankemungkinan terjadinya kegagalan dan efek samping vasektomi yang tidak dikehendaki, sebab perasaan takut akan efek samping yang tidak diinginkan, secara langsung maupun tidak langsung akan menyebabkan partisipasi kaum pria dalam Program KB menjadi terhambat.
\end{abstract}

\section{Latar Belakang Teoritis}

Masalah yang dihadapi beberapa negara berkembang dewasa ini adalah mengurangi jumlah kemiskinan dengan menggunakan berbagai cara baik melalui peningkatkan infrastruktur ekonomi seperti membangun jalan, jembatan, pasar, serta sarana lain, maupun membangun derajat dan partisipasi masyarakat melalui peningkatan pendidikan maupun kesehatan. Namun demikian kendala utama yang dihadapi hampir semuanya sama, yang umumnya bersumber pada permasalahan kependudukan. Mulai dari masih tingginya angka kematian bayi, dan ibu melahirkan, rendahnya kesadaran masyarakat tentang hak-hak reproduksi, serta masih cukup tingginya laju pertumbuhan penduduk, yang tidak sebanding dengan daya dukung lingkungan.

Keprihatinan akan permasalahan kependudukan melahirkan sebuah konsep pembangunan berwawasan kependudukan, atau konsep pembangunan yang bekelanjutan. Dari sini pula lahirlah kesadaran dunia untuk mengurai masalah kemiskinan dan keterbelakangan melalui pendekatan kependudukan. Langkah pertama dan merupakan strategi yang monumental adalah kesadaran lebih dari 120 pemerintah/ negara yang berjanji melalui konferensi internasional tentang pembangunan dan kependudukan (ICPD) di Cairo pada tahun 1994 untuk bersama-sama 
menyediakan pelayanan kesehatan reproduksi bagi semua orang tanpa diskriminasi "Secepat mungkin paling lambat tahun 2015". Langkah besar ini dilanjutkan dengan Millenium Development summit (MDS) pada bulan September 2000 di New York (Amerika Serikat) dengan kesepakatan yang dikenal dengan Millenium Development Goals (MDGs) yang menegaskan tentang komitmennya untuk:

1. Penghapusan kemiskinan dan kelaparan (eradicating extreme povertyand hunger).

2. Mencapai pendidikan dasar yang universal (achieving iniversal basiceducation).

3. Mempromosikan kesehatan gender dan pemberdayaan perempuan (promoting gender equality and empowering women)

4. Mengurangi jumlah kematian anak (reducing child mortality).

5. Meningkatkan kesehatan ibu (improving maternal mortality).

6. Memerangi HIV/AIDS, malaria dan penyakit lain (Combating HIV/AIDS, malaria and other deseases).

7. Menjamin kelestarian lingkungan hidup (ensuring environmental sustainability).

8. Mengembangkan kemitraan global untuk pembangunan (developing aglobal partnership for development).

Selanjutnya dengan adanya perubahan orientasi program tersebut membawa konsekuensi terjadinya pergeseran visi program KB Nasional yang selama ini berupa kelembagaan dan pembudayaan Norma Keluarga Kecil Bahagia dan Sejahtera (NKKBS), berkembang menjadi "Keluarga Berkualitas 2015". Kemudian visi tersebut dijabarkan kedalam 6 misi program, yaitu : (1) Pemberdayaan dan penggerakan masyarakat untuk membangun keluarga berkualitas. (2) Menggalang kemitraan dalam peningkatan kesejahteraan, kemandirian, ketahanan keluarga serta meningkatkan kualitas pelayanan. (3) Meningkatkan kualitas pelayanan $\mathrm{KB}$ dan kesejahteraan reproduksi. (4) Meningkatkan upaya-upaya promosi, perlindungan, dan upaya mewujudkan hakhak reproduksi. (5) Meningkatkan upaya pemberdayaan perempuan dalam mewujudkan kesetaraan dan keadilan gender dalam pelaksanaan program KB nasional. (6) Mempersiapkan pengembangan sumber daya manusia potensial sejak pembuahan dalam kandungan sampai dengan usia lanjut.
Dalam rangka mensukseskan visi dan misi di atas, salah satu masalah yang menonjol adalah rendahnya partisipasi pria dalam pelaksanaan program KB baik dalam praktik $\mathrm{KB}$, mendukung istri dalam penggunaan kontrasepsi, sebagai motivator atau promotor dan merencanakan jumlah anak . 2) Faktorfaktor yang menyebabkan rendahnya kesertaan KB pria antara lain: (1) Kondisi lingkungan sosial, budaya, masyarakat dan keluarga yang masih menganggap partisipasi pria belum atau tidak penting dilakukan. (2) Pengetahuan dan kesadaran pria dan keluarga dalam ber $\mathrm{KB}$ rendah. (3) Keterbatasan penerimaan dan aksesibilitas (keterjangkauan) pelayanan kontrasepsi pria. (4) Adanya anggapan, kebiasaan serta persepsi dan pemikiran yang salah yang masih cenderung menyerahkan tanggung jawab KB sepenuhnya kepada para istri atau perempuan.

Selama ini sudah banyak upaya yang ditempuh oleh DP3AP2KB Kota Blitar dan Kecamatan Kepanjenkidul khususnya untuk meningkatkan partisipasi pria dalam berKB dengan bantuan kondom gratis, kelompok $\mathrm{kB}$ pria di tingkat Kelurahan (7 Kelurahan), penyuluhan, pelatihan petugas untuk melakukan MOP, tersedia tenaga penyuluh lapangan keluarga berencana ditiap-tiap kelurahan, namun partisipasi pria masih tetap rendah. Mengingat dalam penentuan pengambilan keputusan keluarga sebagian besar masih didominasi suami, maka indikator partisipasi pria menurut BKKBN tidak hanya sebagai peserta $\mathrm{KB}$ saja tetapi juga mendukung istri dalam penggunaan kontrasepsi, pemberi pelayanan KB (motivator, testimoni) dan merencanakan jumlah anak bersama pasangan.

Di era globalisasi dan demokratisasi yang semakin mengemukakan isu hak asasi manusia (HAM) dan kesetaraan gender serta kesamaan hak dan kewajiban antara suami dan istri, saat ini kondisi di atas tidaklah dapat dipertahankan, bahkan secara bertahap harus diperbaiki.

Arus globalisasi yang menghendaki tuntutan hak asasi, demokrasi, peningkatan keadilan dan kesejahteraan bercampur dengan keadaan dan sosial budaya dan adat istiadat akan memberikan tekanan dan permasalahan sendiri terhadap program KB.

Di Kota Blitar sesuai kondisi bulan 
Juni 2017 menunjukan bahwa tingkat kesertaan ber-KB sudah cukup baik, dari jumlah Pasangan Usia Subur (PUS) yang ada saat ini (22.003), yang saat ini menjadi Peserta KB Aktif (PA) berjumlah 16.454 (74,78\%). Dari jumlah Peserta KB Aktif (PA) yang ada saat ini, 6.244 akseptor $(37,95 \%)$ merupakan peserta aktif alat kontrasepsi jangka panjang (IUD,MOW,MOP,Implan/sino/implanon).

Dari jumlah tersebut tingkat kesertaan $\mathrm{KB}$ pria (yang menggunakan MOP) berjumlah 514 akseptor (3,12\% dari total PA) sedang partisipasi pria dengan menggunakan alat kontrasepsi non MKJP (kondom) hanya berjumlah 1.053 akseptor $(6,40 \%$ dari jumlah $\mathrm{PA})$. Dengan demikian jumlah kesertaan $\mathrm{KB}$ pria di Kota Blitar masih sangat rendah.

Gambar

Bangun Teori Penelitian

Implementasi Kebijakan Keluarga Berencana Di Kota Blitar

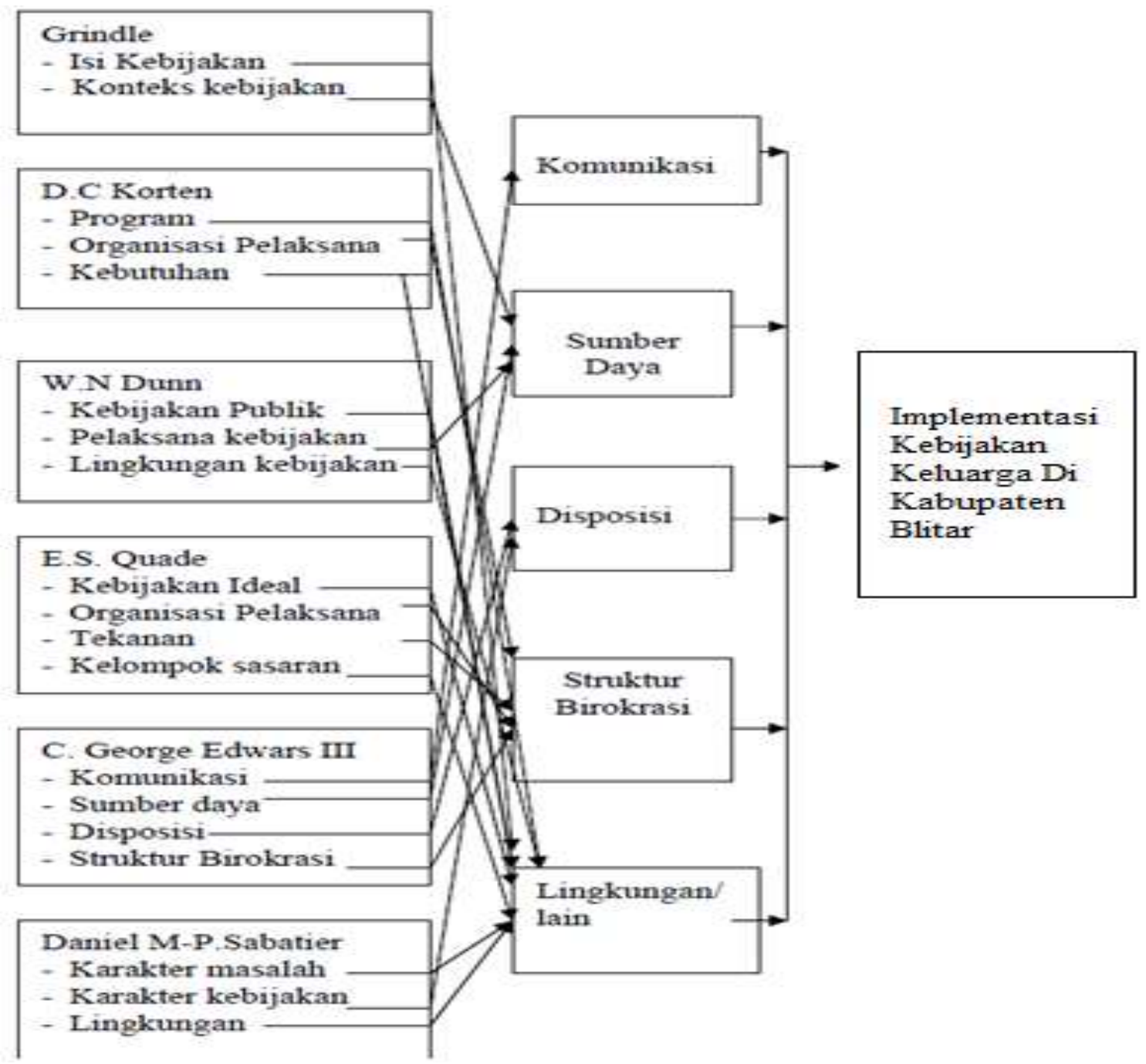




\section{METODE PENELITIAN \\ Pendekatan Penelitian/Perspektif \\ Pendekatan Penelitian}

Penelitian ini menggunakan pendekatan fenomenologis. Hal inimengingat tujuan utama dari penelitian ini adalah untuk memahami secara mendalam terhadap fenomena yang dijadikan sasaran penelitian, yakni masih cukup rendahnya cakupan kesertaan KB pria. Dalam memaknai pemahaman ini, peneliti akan mencoba menarik berbagai generalisasi atau teori yang dapat digunakan untuk perkembangan ilmu itu sendiri atau untuk dijadikan dasar bagi kepentingan aplikasi teori dalam kehidupan masyarakat.

Pertimbangan lain adalah bahwa ilmu administrasi publik merupakan bagian dari ilmu yang tidak mungkin lepas dari aktifitas manusia, sedang manusia adalah sentral dari kajian ilmu itu sendiri. Oleh karenanya untuk memahami berbagai fenomena administrasi publik secara mendalam, penelitian terhadap manusia sebagai pelaku kegiatan sosial itu tidak mungkin diabaikan karena manusia sendirilah yang memberikan warna terhadap sistem administrasi itu sendiri. Berhasil atau gagalnya kebijakan suatu administrasi tidak dapat lepas dari pengaruh sistem sosial budaya masyarakatnya. Upaya untuk memahami fenomena budaya inilah yang menjadi salah satu tugas dari para ahli ilmu administrasi negara dalam mengkaji bidang keilmuannya.

Metode penelitian yang digunakan dalam penelitian ini adalah metodekualitatip. Diharapkan dengan metode ini akan ditemukan makna yangtersembunyi dibalik obyek maupun subyek yang akan diteliti. Metodepenelitian kualitatif sebagai suatu konsep keseluruhan (holistic) berupaya untuk mengungkapkan rahasia sesuatu, dilakukan dengan menghimpun informasi dalam keadaan sewajarnya (natural setting), mempergunakan cara kerja yang sistematik , terarah dan dapat dipertanggungjawabkan secara kualitatif, sehingga tidak kehilangan sifat ilmiahnya. Artinya penelitian ini tidak hanya merekam hal-hal yang nampak secara eksplisit saja, melainkan melihat secara keseluruhan fenomena yang terjadi dalam masyarakat (Nawawi, 1994; 75).

Spesifikasi penelitian akan ditekankan pada penelitian deskriptif analitis, dimana peneliti akan berupaya menggambarkan secara rinci fenomena sosial yang menjadi pokok permasalahan, tanpa melakukan hipotesis dan perhitungan secara statistik. Pilihan perspektif ini sejalan dengan pendapat Bogdan dan Taylor, yang mendefinisikan kualitatip sebagai berikut: "Prosedur penelitian ini akan menghasilkan data diskriptip berupa kata-kata tertulis atau lisan dari orang-orang dan perilaku yang diamati. Pendekatan ini diarahkan pada latar dan individu tersebut secara utuh (holistic) sebagai bagian dari satu keutuhan"(dalam Moleong, 200;3).

Sejalan dengan pendapat di atas, Maustakas menyebutkan, bahwa prinsip,proses, metode fenomenologis adalah sebagai berikut:

1) Fenomenologi memfokuskan pada penampakan suatu benda.

2) Fenomenologi menekankan pada kesatuan, dengan menganalisanya dari berbagai sisi, sudut pandang, dan perspektip sampai mencapai pada satu pandangan yang sama dari satu fenomena yang ada.

3) Fenomenologi berusaha mencari makna dari penampakan dan mencapai pada pemahaman melalui intuisi dan refleksi dari perilaku yang sadar dari sebuah pengalaman, mengarahkan pada ide, konsep, penilaian, dan pengertian.

4) Fenomenologi digunakan untuk menggambarkan pengalaman, bukan untuk menjelaskan dan menganalisa.

5) Fenomenologi berakar pada pertanyaan yang mengarahkan danmemfokuskan pada pemaknaan, dan pertanyaan-pertanyaan

tersebutmengandung penyidikan atau pengungkapan, yang dibangun untukkeperluan dan perhatian lebih jauh, serta memperhitungkan keterlibatan kita dengan hal-hal yang dialami.

6) Subyek dan obyek merupakan satu kesatuan. Apa yang saya lihat, berkaitan dengan bagaimana saya melihat hal tersebut, dengan siapa saya melihat hal tersebut dan sedang bersama siapa saya pada saat itu.

7) Penelitian realitas inter subyektifitas merupakan bagian dari proses.

8) Data tentang pengalaman, pemikiran pribadi, intuisi, refleksi, danpenilaian 
merupakan bukti utama dalam penelitian ilmiah.

9) Pertanyaan penelitian terfokus dan mengarahkan penelitian harus secara hatihati dibangun (Maustakas,1994;58-59).

Oleh karena penelitan kualitatip tidak berangkat dari hipotetis tertentu serta tidak menguji hipotesis, dengan demikian melalui penelitian inidiharapkan dapat menjelaskan secara terperinci faktorfaktor yang mempengarui kekurangoptimalan pencapaian tujuan dari sebuah kebijakanpublik dimaksud, sehingga pada akhirnya dapat memberikan rekomendasi kepada pembuat kebijakan untuk merumuskan kembali penyempurnaan dari kebijakan peningkatan kesertaan KB pria.

\section{Pemilihan Informan}

Sebelum peneliti melakukan pemilihan informan, maka terlebih dahulu ditetapkan situasi sosial atau situasi penelitian, yang merupakan tempat dimana permasalahan atau fenomena sosial yang akan diteliti betul-betul ada.

Dr.Lexy J Moloeng,MA, ( 2005: 3) seperti yang ditulis dalam bukunya Metodologi penelitian Kualitatif, didalam mendapatkan informasi yang benarbenar valid, maka didalam memilih informan dapat dilakukan melaluiwawancara pendahuluan, sebelum melakukan penelitian. Dalam penelitian ini pemilihan informan dilakukan secara tidak acak atau purposive. Cara inidilakukan dengan pertimbangan bahwa informan yang dipilih adalah orangorang yang benar-benar mengetahui atau terlibat langsung dengan fokus penelitian. Informan yang dipilih adalah informan kunci (key informan).

Dengan memperhatikan karakter informan tersebut, maka dalam penelitian ini jumlah informan yang dibutuhkan tidak bisa ditetapkan terlebih dahulu. Proses penelitian berlangsung dari satu informan ke informan yang lain, penyebaran satu informan ke informan yang lain berlangsung secara snow balling(bola salju), yaitu bermula dari seorang informan yang mungkin pengetahuan atau keterlibatan didalam permasalahan yang diteliti relatifsedikit beralih kepada informan yang keterlibatannya lebih besar (Hidayat, 2002:5). Dalam proses peralihan dari informan satu ke informan yang lain tetap memperhatikan karakteristik dari informan, yaitu informan yang betul-betul mengetahui seluk beluk kesertaan $\mathrm{KB}$ pria yangbertempat tinggal di wilayah Kecamatan Kepanjenkidul.

\section{Instrumen Penelitian}

Instrumen utama dalam penelitian ini adalah peneliti itu sendiri, dimana peneliti merupakan alat pencari informasi, menilai keadaan/ tindakan dan mengambil keputusan dalam usaha pengumpulan data. Hal ini sejalan dengan pendapat Moeloeng yang menyatakan bahwa : Hanya "Manusia sebagai alat" sajalah yang dapat berhubungan denganresponden atau obyek lainnya, dan hanya manusialah yang mampu memahami kaitan kenyataan-kenyataan di lapangan. Hanya "manusia sebagai instrumen" pulalah yang dapat menilai apakah kehadirannya menjadi faktor pengganggu, sehingga apa bila terjadi hal demikian ia pasti dapat menghadapinya serta dapat mengatasinya

Sebagai alat Bantu dalam pengumpulan data, digunakan pula buku catatan, kamera untuk merekam gambar-gambar selama proses penelitian berlangsung, serta tape recorder untuk merekam kegiatan selama proses penelitian berlangsung.

\section{Pengumpulan Data dan Pengolahan Data}

Pengumpulan data primer dilakukan dengan dua cara, yaitu wawancara mendalam (indept interview) dan observasi lapangan. Wawancara mendalam. Untuk itu dilakukan dengan metode snow bowling, berangkat dari informan yang sangat terbatas informasinya tentang $\mathrm{KB}$ pria ke informan yang lebih luas dan mendalam informasinya tentang permasalahan yang diteliti. Hal ini dilakukan dengan cara purposive dengan para informan, yakni orang yang dianggap tahu mengenai permasalahan dalam implementasi peningkatan kesertaan KB pria. Agar wawancara dilakukan lebih terarah, dilakukan metode wawancara semi terstruktur (memakai pertanyaan terbuka, dan untuk isu-isu relevan yang tidak diharapkan hendaknya diikuti lagi oleh pertanyaan lanjutan untuk menggali lebih banyak informasi) (Mikkelsen,1999;85). Panduan wawancara sebagaimana terlampir. 
Digunakan intervew, catatan garis besar materi wawancara untukmenggali informasi di lapangan, yang kemudian dikembangkan oleh penelitiselama wawancara berlangsung, sehingga diperoleh informasi sebanyak danseakurat mungkin. Dilakukan pula observasi lapangan untuk melihat secaralangsung kondisi lingkungan dan fakta sosial yang terjadi, sehingga dapatdicocokkan antara hasil wawancara serta fakta sosial yang ada, antara lain Foto, catatan laporan

Digunakan pula data sekunder yang pengumpulannya dilakukan melaluikajian pustaka, sumber tertulis seperti buku, artikel, dokumen, dan lain-lain yang masih ada relevansinya dengan bidang kaji penelitian, dipakai sebagai tambahan referensi untuk memperkaya temuan penelitian.

Proses pengolahan data, bergerak diantara empat sumbu kumparan, yakni bergerak bolak-balik diantara perolehan data, reduksi data, penyajian dan penarikan kesimpulan/verifikasi, artinya data yang berupa catatan lapangan yang terdiri dari bagian deskripsi dan refleksinya adalah data yangdikumpulkan, kemudian disusun pengertian dengan pemahaman arti yangdisebut reduksi data, kemudian diikuti penyusunan sajian data yang berupa cerita sistematis, selanjutnya dilakukan usaha untuk menarik kesimpulandengan ferifikasinya berdasarkan semua hal yang terdapat dalam reduksi data dan sajian datanya. Jika kesimpulan dirasa kurang mantap karenaterdapat kekurangan data dalam reduksi data dan sajian data, maka dilakukan penggalian lagi ke dalam field note. Jika ternyata dalam field note juga tidak dapat diperoleh data pendukung yang dimaksud, maka dilakukan pengumpulan data khusus kembali ke pandalaman dukungan yang diperlukan.

\section{Analisis Data}

Tekhnik analisa data yang digunakan adalah analisis taksonomis(taxonomic analysis), yaitu bentuk analisis yang lebih rinci dan mendalamdalam membahas suatu tema atau pokok permasalahan. Pada analisis ini fokus penelitian maupun pembahasan kendati diarahkan pada bidang atauaspek tertentu, namun pendeskrepsian fenomena yang menjadi tema sentral dari permasalahan penelitian diungkap secara rinci (Zaenal Hidayat; 2002:8).

Adapun langkah-langkahnya meliputi :

1) Pengumpulan data, baik data primer yang berasal langsung darisumbernya, maupun data skunder yang diperoleh dari sumber tidak langsung atau sumber lain.

2) Penilaian data dilakukan dengan prinsipprinsip validitas, yaitu data harus tepat dengan keadaan sesungguhnya, reliabilitas, adanya kesamaan data pada waktu yang berbeda, dan obyektif, data seperti apa adanya tidak dipengaruhi oleh kepentingan tertentu, pendapat, persepsi baik dari orang yang bersangkutan dengan data, maupun dari pihak lain. Sedangkan prosedur untuk memperoleh data yang valid, reliable, dan obyektif antara lain :

a) Kategori data, baik data primer maupun skunder.

b) Mengadakan kritik data, yaitu data tersebut benar atau tidak dibandingkandengan fakta, dan data tersebut relefan atau tidak dengan tujuan penelitian yang hendak dicapai.

3) Interpretasi dan penyajian data, yang diharapkan semua data dapatmembentuk suatu rangkaian yang logis, baik disusun dalam bentuk tabel, persentase, maupun deskripsi.

4) Penyimpulan, dilakukan berdasar dari data dan informasi yang telahtersusun, dihubungkan dengan kajian keilmuan yang sudah difahami dan disiapkan.

\section{Hasil dan Implikasi \\ . Deskripsi Informan}

Dalam penelitian ini peneliti telah mewawancarai 7 informan, dimulai dari beberapa informan kunci (key informan) yang mengetahui betul-betul tentang kebijakan keluarga berencana pada umumnya dan kebijakan peningkatan kesertaan KB Pria khususnya, selanjutnya menggelinding ke arah informan-informan berikutnya hingga dirasa cukup sesuai dengan motode snow-ball (bola sallju). Kriteria dianggap cukup mana kala informasi yang disampaikan cenderung tidak ada farian yang berbeda dari penjelasan informan sebelumnya sehingga oleh peneliti informasi tersebut dianggap sudah jenuh.

a) Informan $I$ 
Beliau seorang Kasi Pemberdayaan Masyarakat di Kecamatan Kepanjenkidul genap berusia 52 tahun mempunyai 3 orang anak, dan umur istri 42 tahun. Mulai bekerja sebagai Kasi di kecamatan tahun 2014, saat ini istrinya ikut KB Suntik dan sudah 12 tahun. Ketika Peneliti menanyakan : Selamat pagi Pak, mau kenapa kok tidak Bapaknya yang mengambil peran untuk menjadi peserta $\mathrm{KB}$ ? jawaban yang diberikannya adalah bahwa yang berkehendak besar untuk ber KB adalah istri, sehingga menyilahkan istri untuk $\mathrm{KB}$ sesuai yang diingnkan, Kebijakan Keluarga berencana umumnya dan peningkatan kesertaan KB Pria saat ini kurang merakyat, yang hal ini disebabkan karena kurangnya sosialisasi tentang $\mathrm{KB}$ pria yang sesungguhnya, serta koordinasi lintas sektoral yang saat ini nampaknya mengendor tidak seperti tempo dulu, dimana peran kepala Daerah sangat membantu suksesnya pelaksanaan program KB. Wawancara yang berlangsung seusai upacara bendera, (kirakira jam 08.30 sampai 09.30 WIB) pada hari Selasa, 17 Juli 2018 di ruang kerja .

b) Informan II

Atas informasi yang didapat dari informan kunci, sehari berikutnya, Rabu, 18 Juli 2018, jam 08.30 sampai dengan 9.30 WIB peneliti mewawancarai informan ke 2 ini. Informan Seorang Penyuluh Keluarga Berencana (PKB), yang istilah sekarangnya disebut sebagai Penyuluh KB Kecamatan Kepanjenkidul. Informan ini berusia 41 tahun, sebelumnya jabatan yang sama diembannya di Kecamatan Sananwetan. Informan bertempat tinggal di Kota Blitar. Ia seorang bapak yang saat ini memiliki 2 orang anak, perempuan dan laki-laki. Anak terakhirnya saat ini berusia 7 Tahun 2 bulan. Ketika ditanya soal alat kontrasepsi KB yang saat ini digunakan serta sejak kapan penggunaannya, informan awalnya hanya tersenyum, baru setelah ditanya kembali, dijelaskannya bahwa sejak kelahiran anak keduanya pasangan ini sepakat untuk menggunakan alat kontrasepsi kondom, yang dimaksudkannya sebagai bentuk kepedulian dan peran serta pria dalam ber keluarga berencana. Dijelaskannya pula bahwa setelah era otonomi daerah Keluarga berencana memang terasa meredup gaungannya, menurutpenuturannya hal ini dipengaruhi beberapa hal;
1) BKKBN Pusat dan Propinsi tidak memiliki kewenangan pembinaan penuh terhadap institusi $\mathrm{KB}$ di Kota/Kab dan Kecamatan,

2) Di era reformasi sekarang ini pendekatan KB tidak lagi tertuju mutlak pada pendekatan demografi murni seperti tahun 80-an, melainkan titik tekan pada kualitas pelayanan dalam memberikan kepuasan klien,

3) Keberadaan lembaga $\mathrm{KB}$ di daerah seperti di Kota Blitar tidak hanya melulu mengelola $\mathrm{KB}$ semata, tetapi berkembang ke masalah Kependudukan dan KB". Mengenai $\mathrm{KB}$ Pria, informan menjelaskannya sebagai bagian dari bentuk nyata partisipasi pria dalam Program KB dan kesehatan reproduksi. Pengetahuan ini ia dapatkan dari beberapa kali mengikuti pelatihan yang diselenggarakanan oleh BKKBN Propinsi maupun secara reguler tiap bulan sekali diadakan rapat koordinasi Program KB tingkat Kota yang isinya disamping menelaah, mengevaluasi kegiatan bulan sebelumnya , merencanakan kegiatan bulan berjalan, juga diisi dengan memberikan pengetahuan baru tentang KB secara umum, maupun kadang-kadang khusus mengenai $\mathrm{KB}$ pria. Kegiatan tersebut kemudian ditindaklanjuti di tingkat kecamatan yang disampaikan kepada PLKB dibawahnya melalui rapat pertemuan (Meeting mingguan) serta Rapat Koordinasi bulanan bersama seluruh PKB dan petugas PPKBD se kecamatanyangisinyasecara detail membahas langkah-langkah yang perlu dilakukan oleh PLKB pembinan Desa serta PPKBD.Namun demikian informan menuturkan ketika disodori pertanyaan "Kenapa program KB Pria kian hari sepertinya kian sulit diterima masyarakat Sebab utamanya adalah gairah kerja PKB cenderung menurun,seperti mereka yang sudah agak sepuh-sepuh, jarang mau menambah wawasan dengan membaca buku paket kiriman dari kota, Sedangkan yang muda-muda meskipun tingkat pendidikannya bagus namun 
frekuensi ke kelurahan mereka sangat kurang.

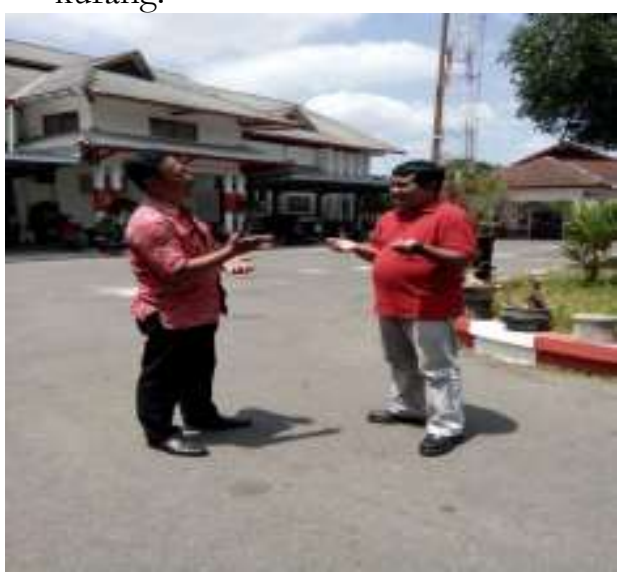

c) Informan III

Informan ini bertugas sebagai Babinsa di Kecamatan Kepanjenkidul sejak tahun 2014 berusia 49 tahun,orang menyebutnya Pak Hajib, tinggal di Kelurahan Bendo, merupakan salah satu Kelurahan dari wilayah Kecamatan Kepanjenkidul, mempunyai anak 3 , sekarang alat $\mathrm{KB}$ yang digunakan adalah MOP (KB Pria) yang digunakannya sejak anak usia 15 tahun. Pendidikan terakhirnya SMA.

Informan memberikan penjelasan;

"Pak, saya sudah lama menjadi Babinsa, mulai tahun 1980, sudah terbiasa bergabung dengan PKB dalam kegiatan Bhaksos di masyarakat di semua kelurahan, tidak perlu membaca bukubuku saja saya sudah terbiasa, sehingga saya tidak perlu menambah pengetahuan baru tentang KB pria, toh satu dua orang bisa saya ajak untuk berangkat pelayanan MOP”

Tentang hambatan program saat ini peneliti menanyakan "Sesuai data, dua tahun terakhir kesertaan $\mathrm{KB}$ pria sangat sedikit, apa hambatannya? pak Hajib meneruskan cerita bahwa menurutnya, yang menjadi penyebab utama ada dua:

1) Kurangnya Media Penyuluhan sehingga hanya lintas sektor yang paham tentang vasektomi, kurangnya frekfensi pertemuan di forum masyarakat

2) Beberapa kejadian kegagalan seperti yang dialami salah seorang akseptor MOP dari Gedog. atau rumor di masyarakat tentang efek samping MOP menjadi "kurang bergairah dan tidak bisa bekerja berat" peneliti menanyakan "Bagaimana sebaiknya agar program $\mathrm{KB}$ pria bisa berjalan baik ?, peneliti juga memberikan penjelasan pertanyakan "yang perlu dibenahi apa: media penyuluhannya, sarana, jumlah petugas perlu ditambah, kelembagaannya, atau fasilitas pelayanannya ?" Informan lagi-lagi tetap menjawab "PLKB-nya disuruh lebih aktif seperti jaman dulu".

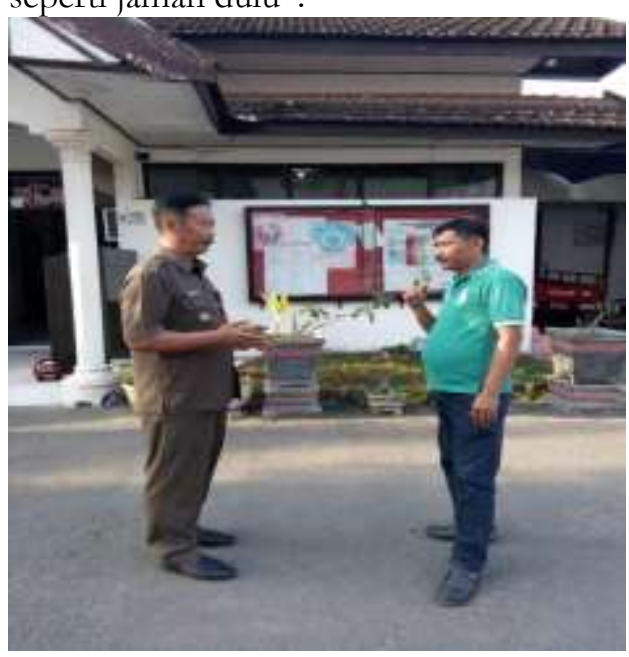

d) Informan IV

Atas dasar informasi yang diberikan informan III,pada hari yang sama serta di ruangan yang sama, Senin, 3 Agustus 2018. Dia adalah PKB usianya 54 tahun, memiliki 3 orang anak, Alat kontrasepsi yang pernah digunakannya ada beberapa macam mulai dari pil, suntik, IUD, dan yang terahir kondom, alasannya "Sudah tua jarang digunakan kok Pak, sewaktu pingin saja cukup pakai kondom" . ketika ditanya mulai kapan, ia tidak ingat, kemudian mengapa tidak menggunakan MOP? ia memberikan jawaban "masih takut" tanpa diterusakan pembicaraannya. Yang ia ketahui tentang KB pria ia menjawab " $\mathrm{KB}$ pria itu Kondom. Upaya menambah wawasan pengetahuan $\mathrm{KB}$ pria ia lakukan dengan membaca brosur di kantor, Tentang tugasnya memberikan penyuluhan, ia memberikan penjelasan bahwa ia tetap memberikan penyuluhan melalui posyandu di dua kelurahan sesuai dengan bidang tugasnya secara rutintiga sampai empat kali dalam sebulannya untuk masingmasing \kelurahan, dan setiap kali ada masalah langsung dikonsultasikan pada Bidang KB atau dirujuk ke Puskesmas. Kemudian ketika peneliti menanyakan "Kenapa kok sekarang KB pria tambahannya 
semakin sedikit ?". Menurut informan alasannya adalah adanya anggapan bahwa MOP menjadi "loyo" atau hilangnya keperkasaan, ia menunjukkan salah satu kasus yang pernah ia temui di Kelurahan Karangtengah. Untuk meningkatkan cakupan kesertaan $\mathrm{KB}$ pria, menurutnya yang penting menghilangkan rumor, dan sekarang masyarakatnya memang sulit dibanding dulu, demikian informan mengakhiri ceritanya.

e) Informan $\mathrm{V}$

Berbekal informasi dari informan III dan IV, sehari berikutnya,Kamis, 2 Agustus 2018, kurang lebih jam 12.00 WIB tanpa janjian lebih dulu, peneliti mencoba ke Rumah seorang informan ini yang ada di Kelurahan Kepanjenlor,Syukur Alkhamdulillah beliau ada di rumah. Mengawali wawancara yang berlangsung di ruang tamu, peneliti sebagaimana biasa seorang tamu, memperkenalkan diri, baru menanyakan identitas diri. Diperoleh informasi bahwa beliau seorang tokoh masyarakat, pekerjaan sehari-hari sebagai tukang sapu dijalan, dengan usia hampir 52 tahun. informan memiliki 6 orang anak, satu meninggal dunia ketika masih kecil,hingga menurutnya dengan lima orang anak dirasa sudah cukup. Atas dorongan bu dokter puskesmas yang sering menemuinya ketika ada Pelayanan Puskesmas keliling (PUSLING) di rumahnya (kebetulan sebagai Pos Puskesmas Keliling) serta atas bujukan ibu Penyuluh KB) waktu itu kira-kira yang dia ingat kejadiannya tahun 2014, ia tertarik untuk ikut KB MOP, dengan alasan kasihan sama istri yang "Ringkih" (mudah terserang penyakit) akhirnya ia memutuskan untuk ikut MOP. Ketika informan sodori pertanyaan "Sebenarnya alat kontrasepsi apa saja yang bisa digunakan untuk pria ?" dengan spontan ia menjawab disamping MOP ada kondom, namun dengan kondom ia tidak suka lantaran terlalu "ribet" hingga ia menuruti saja ketika rombongan Penyuluh KB dengan sejumlah banyak calon akseptor MOP bersama-sama ke Dinas P3AP2KB di Mobil Pelayanan MOP guna menjalani operasi kecil (MOP).

"Kulo yakin rakyat kulo mboten mangertos, sebab kulo sadar, sebagai suami bilih menawi kulo crito dateng tonggo teparo, mesti geger,sedeng KB MOP nembe gencar-gencaripun, pramilo kulo sidem piyambak" (saya yakin, bahwa rakyat saya tidak mengetahuinya, sebab kalau masyarakat tahu, pasti gempar sedang disisi lain program KB MOP lagi gencar-gencarnya, sehingga saya tidak cerita sama sekali)".

"Riyin PLKB, Pak Camat, Bu Dokter niku asring maringi penyuluhan MOP, / safari $\mathrm{KB}$ kulo sering dikengken ngempalaken tiyang-tiyang ingkang gadah anak akeh, lajeng PLKB maringi penyuluhan. Untuk memperjelas, peneliti menanyakan "Apa mungkin karena isu "Loyo" itu Pak?" "mboten Pak, estu, wingi mawon nggih wonten setunggal, Sutar sarirejo, pun biayai piyambak" (tidak,Pak, betul, kemaren saja ada satu akseptor yang dibiayai sendiri). Perubahan status kelembagaan KB sejalan dengan otonomi daerah beliau tidak mengetahui sama sekali.

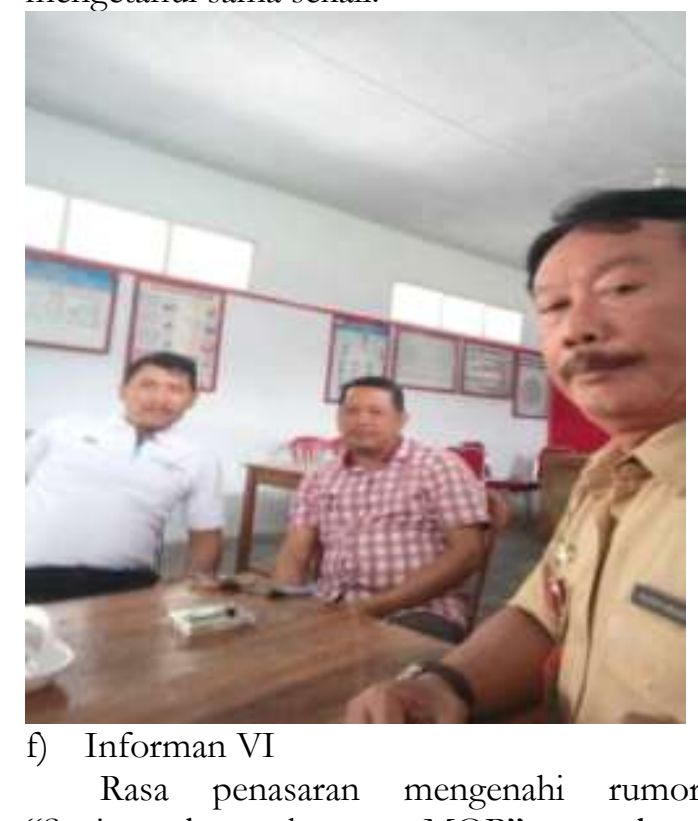
"Senjata loyo karena MOP" membuat peneliti semakin tertantang untuk menelusurinya. Setelah mendatangi informan V,Jum'at, 10 Agustus 2018 kira-kira jam 10.00 WIB peneliti mencoba langsung datang tanpa janjian sebelumnya, menunggu di Kelurahan Sananwetan kurang lebih lima belas menit kemudian, dengan berboncengan perangkat desa lainnya informan yang menjadi target peneliti datang. Sebagaimana biasa dengan memperkenalkan diri maksud dan tujuan penelitian, akhirnya Informan mencarikan tempat di ruang tamu rumah seorang warga sebelah balai Kelurahan untuk berlangsungnya wawancara. Beliau 
seorang Lurah, berusia 54 tahun, jumlah anaknya 3 orang, anak terakhirnya 15 tahun, duduk di bangku SMP, alatkontrasepsi yang digunakan MOP sejak anak terakhir duduk di kelas 1 SMP. Informan tertarik menggunakan MOP, setelah mendapatkan penyuluhan dari PKB ,dulu Pak Heri,dengan tujuan karena sudah tidak ingin anak lagi, sedang tidak menggunakan kondom alasanya sulit, tidak praktis. Ketika peneliti menanyakan isu yang didapat dari Informan $\mathrm{V}$ bahwa Pak Mail "senjatanya loyo setelah MOP". Beliau menceritaan bahwa isu itu tidak benar sama sekali, justru yang ia rasakan sebaliknya. Ia meneruskan cerita bahwa setelah melakukan MOP di Dinas KB, tidak sebagaimana biasanya, ketika bangun tidur yang biasanya senjata tidak hidup, kok malah tegangnya bukan main, dan hal ini pernah saya ceritakan pada para Ibu2 di Balai Kelurahan ketika ada penyuluhan KB bersama PLKB Mengenahi program KB pria sekarang kenapa kok sulit, informan menceritakan, bahwa : "Setelah adanya perubahan kelembagaan di dinasdinas informasi sulit di dapat. Kurang adanya $\operatorname{logo-} \log \mathrm{KB}$ di jalan-jalan, Sebenarnya petugas $\mathrm{KB}$ masih baik, memberikan penyuluhan dimana-mana, seperti PLKB juga masih aktif mengajak masyarakat untuk ber$\mathrm{KB}$.

\section{g) Informan VII}

Pada hari Senin, 13 Agustus 2018 pagi,kurang lebih jam 09.00 peneliti diterima di ruang tamu rumahnya. Informan seorang ibu 2 anak, berusia 35 tahun, bertugas sebagai Petugas Pembantu Pembina KB Desa (PPKBD) Kelurahan Ngadirejo, dengan alat kontrasepsi yang digunakan saat ini suntik. Sebagai seorang kader KB yang bertugas mulai tahun 2008, ia telah mengikuti pelatihan Konseling KB Pria di Badan Pemberdayaan Masyarakat dan KB Kota Blitar. Tentang KB pria ia telah melakukan berbagai upaya penyuluhan KB di Kelurahan, namun yang ia rasakan ketersendiriannya, karena kurang mendapat dukungan dari Lurah, serta Pak RT sehingga hasilnya kurang maksimal. Hambatan lain tentang $\mathrm{KB}$ pria adalah pandangan masyarakat yang menyatakan "yang penting $\mathrm{KB}$, tidak harus laki-laki", serta kemudahan mendapatkan alat kontrasepsi untuk perempuan, seperti pil dan suntik yang cukup Pustu dan lagi pula gratis. Disamping itu ada pandangan dari sementara orang bahwa KB MOP dan MOW (Medis Operasi Wanita) itu haram. Oleh karena itu untuk mendukung suksesnya peningkatan kesertaan KB pria adalah perlunya peran Lurah, Perangkat Desa, Petugas PLKB, serta tokoh agama untuk bersama-sama memberikan penyuluhan ke warga masyarakat dengan sejelas.

\section{Diskripsi Hasil Penelitian Implementasi Program KB Pria}

Sebagaimana disebutkan pada bab-bab awal, bahwapeneliti memfokuskan pada masalah :

A. Bagaimana Implementasi Kebijakan peningkatan kesertaan $\mathrm{KB}$ pria di kecamatan Kepanjenkidul Kota Blitar.

Terbitnya Peraturan Daerah (PERDA) Nomor 03 tahun 2013 tentang Organisasi Perangkat Daerah Kota Blitar, adalah untuk menjawab keraguan pemerintah pusat tentang keberlangsungan dan kesinambungan implementasi program keluarga berencana di daerah pasca otonomi daerah. Namun demikian karena begitu banyaknya kewenangan yang harus dilaksanakan oleh pemerintah daerah sejalan dengan amanat undang-undang nomor 23 tahun 2014 tentang Pemerintahan Daerah yang telah diubah menjadi Undang-Undang nomor 09 tahun 2015 tentang Pemerintahan Daerah khususnya terkait pembentukan jumlah dinas dan perangkat daerah, maka tidak semua kebijakan pemerintah pusat dapat diadopsi utuh oleh daerah, tak terkecuali pemerintah Kota Blitar.

Di tingkat kabupaten/kota, kebijakan Program Keluarga Berencana sejalan dengan peningkatan partisipasi pria dalam program $\mathrm{KB}$ dan kesehatan reproduksi yang muaranya pada peningkatan kesertaan $\mathrm{KB}$ pria diadopsi dan diemplementasikan Oleh BidangPengendalian KB dan Kesehatan Reproduksi yang dikoordinir oleh Kepala Seksi jaminan pelayanan $\mathrm{KB}$.

Regulasi program diatas juga berdampak bagi pengembangan karier di lembaga yang hal ini sedikit banyak mempengaruhi kinerja program, sebagaimana yang terungkap oleh Informan VII, mungkin karena seringnya pergantian pimpinan dan kurangnya informasi ,bisa mempengaruhi program $\mathrm{KB}$ di setiap daerah. 
Faktor yang mempengaruhi Implementasi kebijakan peningkatan kesertaan KB Pria

Pada penelitian ini ada beberapa hal yang mempengaruhi implementasi kebijakan peningkatan kesertaan KB Pria di kecamatan kepanjenkidul Kota Blitar, diantaranay : . Komunikasi Informasi dan Edukasi (KIE)

Dalam implementasi program KB umumnya dan peningkatan kesertaan $\mathrm{KB}$ pria khususnya amat ditentukan dari beberapa unsur yang terdapat dalam KIE, seperti penyampai pesan, isi pesan, media yang digunakan, serta sasaran penerima pesan, serta perubahan sebagai akibat komunikasi. Mengenai bagaimana dimensi komunikasi yang terjadi di Kecamatan Kepanjenkidul dapat dideskripsikan sebagai berikut :

Penyampaian pesan

Faktor yang amat menentukan dalam komunikasi adalah kemampuan orang yang menyampaikan pesan. Dari sinilah pesan akan ditransmisikan kepada sasaran atau peneriman pesan. Penyampai pesan dalam hal ini adalah penyuluh keluarga berencana yang dalam tugasnya disamping sebagai pemberi penyuluhan juga berfungsi sebagai perencana sekaligus penyelenggara kegiatan penyuluhan, namun dalam prakteknya terdapat keluhan dari informan seorang petugaspembantu pembina KB Desa /PPKBD (informan VII), seperti terlontar :

"Sebaiknya yang mengajak KB itu tidak hanya saya sendirian,Pak..... perlu melibatkan Pak Lurah, Perangkat, dan PLKB

Kemudian informan lain, seperti informan V mengatakan : "Menurut saya penyebab sepinya KB Vasektomi itu bersumber dari petugasnya, dulu PLKB, Pak Camat, mengadakan kampanye vasektomi/ dikenal safari KB Keliling di setiap kelurahan bersama Babinsa dan tokoh masyarakat juga, bahkan ada beberapa Lurah katanya melakukan vasektomi, tetapi sekarang sudah tidak ada.

Media yang digunakan

Disamping faktor penyampai pesan, media yang digunakan juga amat menentukan berhasil dan tidaknya suatu komunikasi mencapai target sebagaimana yang diinginkan penyampai pesan. Oleh karena itu pemilihan media merupakan salah satu kunci keberhasilan suatu komunikasi. Beberapa informan menyebutkan bahwa balai desa dan pertemuan PKK sebagai media utama yang digunakan PLKB untuk menyampaikan pesan KB Pria.

Penyampaian Isi Pesan

Kendati isi pesan mengacu pada panduan materi konseling, namun keutuhan, kelengkapan serta sistematika penyampaian yang disampaikan kurang sempurna dan sistematis, maka kualitas komunikasi akan menjadi bias. Olehkarena itu isi pesan juga harus mendapat perhatian dalam sebuah komunikasi.Kondom sebagai alat kontrasepsi pria telah banyak dikenal oleh informan, namun tidak demikian untuk Medis Operasi Pria (MOP) yang kurang dikenal diantara para informan, seperti yang telah disampaikan informan VI tidak adanya logo2 KB di jalan.

Presepsi negatif dari calon akseptor

Ketiadaan atau kurangnya pesan KB pria serta media yang disampaiakn tidak tepat sasaran, maka akibat komunikasi menjadi bias, ada yang menyebut MOP itu menjadi ringkih, impoten, serta menjadi gemuk, seperti tergambar:

"...... wah kulo wedi, lha..... wong...jarene wong wedok, menawi MOP ndadoske ringkih..... "( wah saya takut, kata istri saya kalau melakukan vasektomi/MOP menjadikan badan tidak bisa bekerja keras)

Sumber daya

Jumlah PLKB Kecamatan

Kepanjenkidul semuanya berjumlah 5 orang petugas, serta 1 (satu) orang diantaranya sebagai koordinator. Semuanya berpendidikan S-I, sedangkan jumlah kelurahan ada 7, sehingga ada beberapa yang merangkap wilayah. Upaya peningkatan kualitas penyuluh KB juga disebabkan karena kurang adanya peningkatan kualitas melalui pelatihan pelatihan khusus seperti tempo dulu waktu program $\mathrm{KB}$ masih vertikal. Hal ini sebagaimana diungkapkan oleh responden PLKB .

Koordinasi antar stakeholder sebagaimana yang pernah dilakukan tempo dulu nampaknya sekarang jarang sekali diselenggarakan baik yang bersifat formal seperti rapat koordinasi, maupun yang sifatnya informal oleh pelaksana kebijakan di tingkat Kecamatan.

Sedangkan faktor faktor yang mempengaruhi peningkatan kesertaan KB pria lainya adalah

1. Disposisi 
Ada beberapa hal penting terkait dengan disposisi implementator; respon implementator terhadap kebijakan, kognisi, serta freferensi nilai yang dimiliki. Rendahnya responsifitas petugas terhadap kebijakan , misalnya karena minimnya jumlah petugas maka kurang maksimal kegiatan dilapangan dan juga seringnya kegiatan di tingkat kota yang melibatkan semua PKB.Selain itu kurangnya perhatian dari petugas apabila ada keluhan dari bawah terkait penyuluhan Vasektomi yang tidak ada dukungan dari lembaga lain.

Data Petugas KB

Tingkat Pendidikan Penyuluh KB di Kecamatan Kepajenkidul

\begin{tabular}{|c|l|c|c|}
\hline No & $\begin{array}{c}\text { Jenjang } \\
\text { Pendidikan }\end{array}$ & Jml PKB & PPKBD \\
\hline 1 & PT/D-IV & 5 & 0 \\
\hline 2 & D-III & 0 & 0 \\
\hline 3 & D- I/D-II & 0 & 0 \\
\hline 4 & SLTA & 0 & 7 \\
\hline
\end{tabular}

\section{Kognisi}

Penggunaan media penyuluhan yang konvensional, menunjukkan betapa pemahaman kebijakan peningkatan kesertaan KB pria yang seharusnya dapat melalui kebijakan pelayanan di tempat kerja, seperti memberikan penyuluhan di pangkalan becak, pangkalan ojek serta tempat kerja para bapak-bapak yang lain tidak pernah dilakukan oleh petugas PLKB.Pengetahuan tentang media yang dimiliki oleh petugas terbatas hanya balai kelurahan sebagai tempat penyuluhan, sementara itu sesungguhnya informan menginginkan pesan $\mathrm{KB}$ pria bisa sampai ke telinganya, sehingga dibutuhkanpenyesuaian waktu dan tempat penyuluhan bagi bapakbapak yang tidak punya akses terhadap Balai Kelurahan.

\section{Freferensi nilai}

Keteladanan untuk menggunakan alat kontrasepsi pria hanya ditunjukkanoleh 3 (tiga) orang petugas, 2 (dua) orang petugas menggunakan kondom dan satu orang PLKB menggunakan MOP.

Fenomena semacam ini sedikit banyak akan mempengaruhi pandangan kelompok penerima program (masyarakat) ketika kemungkinan di salah satu kesempatan menanyakan "Kenapa petugasnya tidak memanfaatkan alat kontraspsi pria ?"

Dari beberapa permasalahan yang telah dideskripsikan oleh peneliti maka dapat dihimpun dengan jelas faktor faktor yang mempengaruhi lemahnya implementasi kebijakan program KB di Kecamatan Kepanjenkidul Kota Blitar,

\section{Diskusi}

Sebagaimana di kemukakan pada bagian awal dalam tesis ini bahwa faktor-faktor yang mempengaruhi kebijakan menurut George C. Edward III (1998) adalah komunikasi, sumber-sumber, disposisi, dan struktur birokrasi. Ke-empat dimensi ini dalam konteks kebijakan peningkatan kesertaan KB pria di Kecamatan Kepanjenkidul nampak ada kesesuaian, walaupun derajat kepentingan masing-masing dimensi tidak segaris. Dimensi kemunikasi amat menentukan dalam berhasilnya suatu program karena dengan komunikasi yang baik, akibat komunikasi yang ditimbulkan juga akan berbuah baik, oleh karena itu penyampai pesan merupakan hal yang mutlak harus diperhatikan, hal ini sejalan dengan pendapat Edward III yang menjelaskan persyaratan utama bagi implementasi yang efektif adalah bahwa para pelaksana kebijakan harus mengetahui apa yang harus mereka lakukan,

keputusan kebijakan harus disalurkan (transmission) kepada orang -orang yang tepat, sehingga komunikasi harus akurat diterima oleh para pelaksana, kemudian jika kebijakan akan diterapkan, maka perintah kebijakan harus diterima dengan jelas (Clarity) selain itu perintah kebijakan harus konsisten (consistecy). Realitas di lapangan mennunjukkan bahwa komunikasi yang baik belum dilakukan secara maksimal, yang hal ini ditunjukkan dengan masih banyaknya rumor yang menyebutkan bahwa MOP mengakibatkan "Senjata menjadi loyo, kemudian menjadikan "badan cepat gemuk seperti dikebiri" dan sebagainya. Yang kesemuanya itu belum diupayakan penjelasan yang lebih rinci dan tepat sasaran. Dalam konteks kebijakan publik, sumber daya manusia dan dana juga memiliki peran yang amat menentukan, karena dengan sumber daya dan sumber dana yang memadai dan berkualitas kebijakan akan dapat dikomunikasikan kepada sasaran penerima kebijakan dengan baik pula, sebaliknya juga, 
sebagaimana realitas yang ada dalam kebijakan peningkatan kesertaan $\mathrm{KB}$ pria ini meskipun pendanaan sudah tidak menjadi persoalan, karena ditopang dari tiga sumber (APBD Kabupaten, APBD provinsi, serta APBN), namun nampak sekali bahwa sumber daya manusia yang dimiliki kurang memadai baik dari sisi usia, tingkat pendidikan, peningkatan kualitas serta dana yang tersedia, sehingga hasil kebijakannyapun kurang maksimal. Dari sisi ini pula koordinasi antar stakeholders kurang dilakukan secara maksimal untuk dapat menghilangkan rumor menjadi kesan yang positif dan menyenangkan.

Disposisi implementator sebagaiamana yang dikemukakan oleh AG Subarno, mencakup

(1) respons implementator terhadap kebijakan yang akan mempengaruhi kemampuannya untuk melaksanakan kebijakan,

(2) kognisi, pemahaman para implementator terhadap kebijakan yang dilaksanakan,

(3) intensitas disposisi implementator, yakni freferensi nilai yang dimiliki oleh implementator. Fenomena realitas kebijakan di lapangan menunjukkan hal yang kurang mendukung, hal ini nampaknya juga disebabkan karena rendahnya kualitas sumber daya yang dimiliki implentator.Kultur birokrasi di Indonesia yang nuansanya cenderung topdown, budaya minta petunjuk dan arahan dari atasan, serta kecenderungan yang ABS (asal bapak senang), ketika ada atasan pura-pura rajin, dan sebaliknya ketika atasan hilang kerjanyapun malas, dijumpai juga pada kebijakan Keluarga Berencana di wilayah penelitian. Kondisi demikian dirasakan betul oleh penangung jawab program di tingkat kecamatan, namun demikian karena suatu program sudah sangat melembaga serta ketergantungan penerima program terhadap birokrasi semakin berkurang, sehingga kebijakan tetap bisa berjalan dengan baik. Sisi lain yang cukup menghambat kesertaan $\mathrm{KB}$ pria juga diakibatkan karena sikap petugas yang sudah merasa bisa tanpa harus menambah wawasan baru seperti ungkapan.
Sebagai sebuah kebijakan pemberdayaan masyarakat, teori George C. Edward III (1998) yang cenderung lebih memperhatikan aspek internal implementator, dalam konteks kebijakan di lapangan realitas menunjukkan hal yang kurang signifikan. Hal ini dapat ditunjukkan seperti budaya masyarakat, yang masih menganut pola bapak, dimana peran bapak dalam keluarga sangat dominan,sebagaimana diungkapkan seorang informan yanag menyebutkan "Pada umumnya yang $\mathrm{KB}$ itu kan perempuan, maka kamu saja mah.... yang KB", informan lain menyebutkan "Sudah sewajarnya seorang istri yang harus prihatin, yang ikut KB" informan yang lain lagi “

\section{Kesimpulan}

Pertama, partisipasi laki-laki (suami) dalam ber-KB relatif masih rendah. Hal ini terlihat dari temuan studi ini, yaitu dari seluruh responden (laki-laki) sebanyak 8,35 persen yang menggunakan kontrasepsi vasektomi, selebihnya perempuan (istri) yang menggunakan metode kontrasepsi. Banyak laki-laki yang memandang bahwa urusan KB adalah tanggung jawab perempuan. Meskipun demikian jika karena alasan kesehatan, misalnya perempuan tidak dimungkinkan menggunakan alat kontrasepsi, maka laki-laki akan menggunakannya.

Kedua, beberapa kendala yang menghambat partisipasi laki-laki dalam ber$\mathrm{KB}$ adalah adanya kekhawatiran mengganggu kejantanan, impotensi, malu karena menjadi pergunjingan di masyarakat. Oleh karena itu, Pasangan Usia Subur (PUS) cenderung menggunakan kontrasepsi yang khas untuk perempuan, seperti pil, IUD, suntik dan susuk. Studi ini juga menemukan kendala yang menghambat partisipasi laki-laki dalam ber-KB justru datang dari istri, bahwa tidak sedikit istri (perempuan) yang tidak setuju apabila suaminya melakukan vasektomi.

Di lingkungan masyarakat yang patriarkhis, pertimbangan yang rasional menjadi penting. Kesediaan responden pria untuk menggunakan metode kontrasepsi pria ternyata juga tidak terlepas dari pertimbangan rasional. Ada resiko atau tidak --baik terhadap isteri mau pun suami-- nampaknya menjadi dasar pertimbangan serius bagi kaum pria dalam memutuskan bersedia atau tidak untuk ber-KB. Artinya jika manfaat yang 
didapatkan responden ketika mereka menggunakan metode kontrasepsi dinilai lebih kuat bagi keluarga, maka mereka akan memiliki kemungkinan kuat pula untuk menggunakan metode kontrasepsi pria. Dalam hal ini faktor dampak terhadap kesehatan tubuh pasca penggunaan metode kontrasepsi tampaknya menjadi salah satu pertimbangan kuat mereka.

Ketiga, strategi yang perlu dikembangkan untuk meningkatkan partisipasi laki-laki dalam ber-KB antara lain adalah: 1) untuk mengurangi berbagai kekhawatiran suami maupun istri tentang risiko ber-KB Pria, khususnya vasektomi, perlu dilakukan sosialisasi yang lebih intensif, dan kampanye Masyarakat, melalui media massa, yang menampilkan bintang iklan yang populer, sehingga keikutsertaan dalam Program KB Pria tidak lagi dianggap sebagai sesuatu yang tabu atau memalukan. Sosialisasi ini perlu dilakukan tidak hanya bagi kaum pria, tetapi juga bagi kaum perempuan, karena dalam kenyataan tidak jarang terjadi justru kaum perempuan sendiri yang menjadi penghalang kemungkinan suami mereka ikut serta dalam Program KB; 2) Untuk mempermudah akses para suami yang ingin melakukan vasektomi, ada baiknya jika dikembangkan berbagai pelatihan bagi para dokter atau tenaga medis lainnya dalam melakukan praktik vasektomi agar bisa dieliminasi sekecil-kecilnya kemungkinankemungkinan terjadinya kegagalan dan efek samping vasektomi yang tidak dikehendaki, sebab perasaan takut akan efek samping yang tidak diinginkan, secara langsung maupun tidak langsung akan menyebabkan partisipasi kaum pria dalam Program KB menjadi terhambat.

\section{Saran/Rekomendasi}

1) Perlunya peningkatan kualitas komunikasi, baik isi pesan yang disampaikan maupun media yang digunakan sehingga akibat komunikasi yang ditimbulkan dapat lebih tepat sasaran dan dapat diterima dengan baik dan sempurna, yang pada akhirnya memberikan kontribusi positif terhadap peningkatan kesertaan KB pria.

2) Perlunya menentukan jenis kelembagaan yang tepat dan pasti di tingkat lapangan (kecamatan) sehingga lebih memberikan kejelasan wewenang dan tanggungjawab terhadap pimpinan di lapangan dalam memberdayakan petugas lapangan (PLKB) dalam mengelola program keluarga berencana pada umumnya dan peningkatan kesertaan $\mathrm{KB}$ pria pada khususnya.

3) Perlunya peningkatan kerjasama dengan instansi terkait seperti Dinas kesehatan, Departemen Agama serta LSOM yang ada di semua jenjaang pemerintahan dalam memberikan penyuluhan pada tokoh masyarakat di desa, sehingga kesan negatif terhadap KB pria seperti menjadi ringkih, loyo kemampuan seksnya, menurunnya libido seks, serta persoalan KB dari sisi agama yang masih ada anggapan sesuatu yang harus dijahui akan semakin kecil yang akhirnya berubah menjadi kesan positif.

4) Untuk para peneliti yang tertarik dengan kajian masalah keluarga berencana dan kesehatan reproduksi dapat lebih memfokuskan pada sisi identifikasi keinginan masyarakat dalam menggunakan alat kontrasepsi. Hal ini disamping akan membantu memberikan alternatif kebijakan yang diperlukan dalam program keluarga berencana, juga bermanfaat dalam penigkatan kesertaan $\mathrm{KB}$ pria.

Untuk meningkatkan peran dan keterlibatan kaum laki-laki dalam Program $\mathrm{KB}$, saat ini kebijakan dan program yang dikembangkan diarahkan kepada: Pertama, peningkatan dukungan politis, sosialbudaya dan keluarga melalui kegiatan advokasi, promosi dan KIE secara intensif kepada para pengambil keputusan, TOMA/TOGA dan sasaran lain yang strategis termasuk anggota keluarga. Kedua, peningkatan intensitas dan kualitas pelayanan promosi dan konseling $\mathrm{KB}$ dan kesehatan reproduksi dengan penekanan tema sentral "laki-laki bertanggungjawab". Ketiga, peningkatan promosi dan konseling untuk meningkatkan pengetahuan dan kesadaran masalah kesetaraan dan keadilan gender. Keempat, peningkatan akses dan kualitas pelayanan bagi laki-laki untukmeningkatkan kesertaan dan partisipasi dalam KB dan kesehatan reproduksi.

\section{DAFTAR PUSTAKA}

BKKBN, 2005.Badan Kesehatan Keluarga Berencana. Indonesia 
BKKBN. 2006. Peningkatan Partisipasi Pria dalam Keluarga Berencana danKesehatan Reproduksi di Indonesia. http://www.bkkbn.go. id/diftor/download.php?

BKKBN. 2009. Peningkatan Partisipasi Pria dalam Keluarga Berencana danKesehatan Reproduksidi Indonesia. http://www.bkkbn.go.id/diftor/ download.php?

BKKBN.2007. Gender dan Program Keluarga Berencana. http://gempria.bkkbn.go.id/artikel02 .21

BKKBN. 2006. Faktor, Data dan Informasi Kesenjangan Gender di Indonesia; Jakarta

BKKBN. 2006. Faktor-Faktor yang Mempengarubi Rendabnya Rartisipasi Priadalam Keluarga Berencana. http.Z/www.bkkbn. go. id/gemapra/info-detal.php?infid=79.

BKKBN, 2005. Peningkatan Partisipasi Pria dalam KB \&.OT.Bkkbn. Jakarta

BKKBN,2004.Peningkatan Partisipasi Pria dalam Keluarga Berencana dan Kesehatan Reproduksi. Jakarta.

Himawati, A. 2010. Sekilaa Informasi Tentang Kependudukan dan Program KB Nasional. Jakarta. BKKBN.

Notoadmodjo, S. 2007. Promosi Kesehatan dan Ilmu Perilaku. Rineka Cipta: Jakarta.

Reza. 2011. Keluarga Berencana dan Kontrasepsi. Pustaka Sinar Harapan. Jakarta.

Sulistyawati, A. 2011. Pelayanan Keluarga Berencana. Salemba Medika: Jakarta.

Yunus, N.P. 2009. Program KB Nasional. Jakarta: BKKBN. 